Research, part of a Special Feature on New Methods for Adaptive Water Management

\title{
Practices and Lessons Learned in Coping with Climatic Hazards at the River-Basin Scale: Floods and Droughts
}

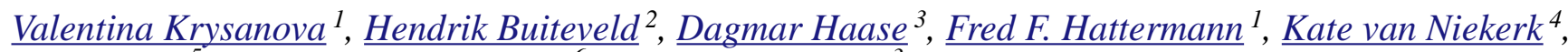 \\ $\underline{\text { Koen Roest }}^{5}, \underline{\text { Pedro Martínez-Santos }}^{6}$, and $\underline{\text { Maja Schlüter }}^{3}$
}

\begin{abstract}
Climatic hazards such as floods and droughts have always been a primary matter of concern for human populations. Severe floods damage settlements, transport networks, and arable land. Although devastating droughts are harmful primarily for agriculture and terrestrial ecosystems, they can also lead to local water supply shortages. Despite significant achievements in science and technology and success stories in environmental management in the 20th century, people still continue to suffer the consequences of climate hazards worldwide. This paper provides an overview of existing practices for coping with floods and droughts, compares strategies in different river basins, and outlines the areas that need improvement. First, the existing protection measures and response strategies against floods and droughts are briefly described. An overview is given of expected climate change and existing coping strategies for floods and droughts in seven case study basins. Four of the basins, namely the Elbe, Guadiana, Rhine, and Tisza, are located in Europe; the Nile and the Orange are in Africa; and the Amudarya is in Central Asia. Analysis of the coping strategies shows that structural measures exist in all seven river basins, but that nonstructural measures are generally not very extensive and/or advanced. Finally, the success stories in dealing with climatic hazards and lessons learned, taken partly from the seven case study basins and partly from literature, are summarized.
\end{abstract}

Key Words: Amudarya; climate change; climatic hazards; coping strategy; drought; Elbe; flood; Guadiana; Nile; Orange; Rhine; Tisza; water resources management

\section{INTRODUCTION}

Climatic hazards have always been a foremost matter of concern to the human population. Although there have been significant achievements in science and technology in the 20th century, people still continue to suffer the consequences of severe floods and droughts on all continents. Floods endanger human life, cause damage to settlements and transport networks, and destroy human heritage. Devastating droughts are harmful for agriculture and may create problems in water supply. Droughts can be connected with heat waves, i.e., extended time intervals of abnormally and uncomfortably hot weather lasting from several days to several weeks, which can be harmful for human health.

According to the World Water Council, economic losses from weather and flood catastrophes have increased ten-fold over the past $50 \mathrm{yr}$, partially as a result of rapid climate changes. These rapid climate changes are seen in more intense rainy seasons, longer dry seasons, stronger storms, shifts in rainfall seasons, and rising sea levels. More disastrous floods and droughts have been the most visible manifestation of these changes (Eisenreich 2005).

In view of the developing issue of climate change, floods and droughts may become more frequent. According to the Clausius-Clapeyron law, the atmosphere's water-holding capacity increases with temperature, and hence the potential for more intense precipitation increases. Also, warming of the atmosphere will lead to increased evaporation from the oceans, and, as a result, to increased precipitation. However, the Earth's climate system functions in such a way that some regions, e.g., in high latitudes and tropics, will experience higher

${ }^{1}$ Potsdam Institute for Climate Impact Research, ${ }^{2}$ Center for Water Management, ${ }^{3}$ UFZ - Helmholtz Centre for Environmental Research, ${ }^{4}$ Institute of Natural Resources, ${ }^{5}$ Alterra - Wageningen University and Research Centre, ${ }^{6}$ Complutense University 
precipitation, whereas others will receive less rainfall (Intergovernmental Panel on Climate Change (IPCC) 2007a). In addition, regional differences are possible because of local topographical conditions. Therefore, climate change has the potential to increase the frequency of extreme events globally by increasing flood risk in some regions, increasing drought risk in others, and even increasing the occurrence of both floods and droughts in some parts of the world (IPCC 2007b).

Set against this background, our paper focuses on flood and drought problems in seven large river basins, i.e., the Amudarya, Elbe, Guadiana, Nile, Orange, Rhine, and Tisza, as reflected in existing and absent protection strategies and measures. The objective is to analyze and compare the case-study basins in this respect by trying to answer the following questions:

1. Are flood and/or drought risks expected to increase in the basins?

2. Which measures exist in the basins now to cope with climatic hazards?

3. Which measures need to be introduced or improved to better cope with extreme events in the future?

We also outline success stories and lessons learned from coping with extreme events. To set the framework for the analysis, an overview of protection measures and response strategies against floods and droughts is given in the first two sections. The next two are devoted to case studies of seven basins that describe expected climate change, climatic hazards, and existing strategies for responding to extreme events. The material for the case studies was collected during interviews with stakeholders and at workshops as well as from the literature. The last section includes a comparative analysis of the coping strategies in the case studies and a description of success stories and lessons learned, which could be helpful to validate water management strategies for dealing with impending climate change in these and other large river basins worldwide. "Coping strategy" in this context is understood to mean a set of measures at the riverbasin scale, including regional, governmental, and local community and household-level actions.

\section{FLOODS: PROTECTION MEASURES AND RESPONSE STRATEGIES}

Floods are caused by extremely intense or extremely long rainfall events, by intense snowmelts, or a combination of both. Floods are usually followed by inundation, when water spills beyond the river channel. Examples of recent severe floods are: the Storm Surge Flood in 1991, which killed 140000 people, and disastrous floods in 1998 and 2007 in Bangladesh; the Midwest Flood of 1993 in the United States; two floods of a 100-yr flood size on the Rhine in 1993 and 1995; the flood in 1996 in South Korea; floods in 1996 and 1998 in China; the devastating flood in 1997 on the Oder in Poland and Germany; a flood in 2000 in Mozambique; a flood in August 2002 on the Elbe in Germany and the Czech Republic; and recent floods in 2005 and 2006 on the Danube (Kundzewicz and Kaczmarek 2000).

Based on data from 1950 to 1998, Berz (2001) evaluated the number of great flood disasters worldwide, which he defines as events in which international or inter-regional assistance is necessary. He concluded that their number has increased considerably over recent decades: six cases in the 1950s, seven in the 1960s, eight in the 1970s, 18 in the 1980s, and 26 in the 1990s. The same tendency has been observed in Europe. Between 1975 and 2001, 238 flood events were recorded in Europe, and the annual number of flood events has clearly increased (European Environment Agency (EEA) 2004).

\section{Protection Measures}

Table 1 outlines major flood protection measures subdivided into structural or technical measures and nonstructural measures, which include social measures and measures taken in watersheds. In this context, it is important to underline that increasing water storage in watersheds by different methods, e.g., restoring wetlands, increasing groundwater storage, limiting pavement in settlements, and planting catch crops, serves to mitigate both types of extreme events: floods and droughts.

Besides climate change, there are a number of anthropogenic factors that contribute to increasing flood risk and the damage caused by floods. Among them the most important are: (1) the reduction of the water storage capacity in watersheds as a result of river regulation, e.g., by straightening, shortening, and drying small tributaries, wetlands, 
Table 1. Major flood protection measures.

\begin{tabular}{|c|c|c|}
\hline \multirow[t]{2}{*}{ Structural measures } & \multicolumn{2}{|c|}{ Nonstructural measures } \\
\hline & Measures in watersheds & Social measures \\
\hline Dams & $\begin{array}{l}\text { Increase natural water retention and } \\
\text { water storage in watersheds by } \\
\text { extending floodplains and creating } \\
\text { wetlands and polders }\end{array}$ & $\begin{array}{l}\text { Flood mitigation systems including } \\
\text { forecasting, warning, evacuation, and } \\
\text { postflood recovery }\end{array}$ \\
\hline Levees & $\begin{array}{l}\text { Enhance infiltration and retardation of } \\
\text { water by reducing impermeable areas, } \\
\text { building groundwater cisterns, etc. }\end{array}$ & Land-use planning \\
\hline $\begin{array}{l}\text { Water storage reservoirs for flood } \\
\text { control }\end{array}$ & $\begin{array}{l}\text { Agriculture practices reducing runoff, } \\
\text { e.g., catch crops, no black fallow in set- } \\
\text { aside areas }\end{array}$ & $\begin{array}{l}\text { Local and transboundary emergency } \\
\text { committees }\end{array}$ \\
\hline $\begin{array}{l}\text { Off-stream polders or flood retardation } \\
\text { ponds }\end{array}$ & $\begin{array}{l}\text { Zoning to delineate floodplain, in } \\
\text { which only low-value infrastructure is } \\
\text { allowed }\end{array}$ & $\begin{array}{l}\text { Household mitigation and preparedness } \\
\text { actions }\end{array}$ \\
\hline Dikes & $\begin{array}{l}\text { Appropriate construction methods in } \\
\text { flood-prone areas }\end{array}$ & $\begin{array}{l}\text { Capacity building to improve flood } \\
\text { awareness, understanding, and } \\
\text { preparedness }\end{array}$ \\
\hline River embankments and floodwalls & & Risk spreading through flood insurance \\
\hline
\end{tabular}

and riparian zones along rivers; by deforestation and degradation of vegetation; and by urbanization, which increases the amount of area covered by impermeable surfaces. Also important are (2) human activities such as settlements, commercial infrastructure, and agriculture in flood-prone areas. Table 2 provides some examples of human actions in river basins, their water-related consequences, and their negative impacts.

\section{Response Strategies}

The failure of structural measures to prevent floods has long been recognized, and several recent destructive floods on different continents have also contributed to the shift in approach. It has become clear that physical or structural protection measures such as dams, storage reservoirs, and embankments alone cannot completely protect against floods (Kundzewicz and Takeuchi 1999). Although they are still necessary for flood protection, particularly in urban areas, modern flood response strategies should rely on an integrated approach that includes all three types of measures: (1) maintaining and updating structural flood protection, (2) enhancing water storage capacity in watersheds using different means, and (3) strengthening social mitigation measures such as land-use planning, forecast and warning systems, community emergency planning, and household mitigation actions. The importance of these different types of measures is, of course, site specific and should be assessed in a regional context. If it is to be successfully implemented, an integrated approach must consider the technical and land-use measures that are related to the social and political drivers of behavior within societies. 
Table 2. Examples of human actions in river basins, their water-related consequences, and negative impacts.

\begin{tabular}{ll}
\hline \hline Action & Water-related consequences \\
\hline Urbanization: water supply from the & Increase in impervious areas \\
upstream part of the basin or from & Increase in peak discharge and surface \\
the groundwater system & runoff \\
& Point and diffuse source pollution \\
& Decrease in groundwater recharge
\end{tabular}

Intensification of agriculture: high amounts of fertilizers, pesticides, and herbicides in use; irrigation; high livestock densities

Extensification of agriculture: use of Higher runoff more land for agricultural production, ploughing of extensive areas, irrigation

Forestation

Dam construction: reservoirs and impoundments for flow regulation to meet human requirements, water supply, hydropower production, flood control, and navigation

Channelization by straightening, shortening, and converting natural channels to concrete ones

Irrigation

Excessive water withdrawals from groundwater
Higher runoff in the nongrowing season Lower runoff in the growing season

Increase in water storage

Enhanced evaporative losses

Reduced runoff

Reduced total annual streamflow

Changes in downstream flow

to Streamflow regulation, i.e., storing water when abundant and releasing when scarce Flood control

Reduction in the times to peak Faster conveyance

Persistent water loss through deep percolation, causing local groundwater table to rise

Entrance of natural salts into soil horizon close to the surface by capillary rise Irrigation with salt water Salt washes off the land during stormflow or enters river with baseflow

Lower groundwater table
Negative impacts

Higher flood risk

Possible water quality problems downstream

Associated diffuse source pollution Eutrophication of waterbodies Salinization

Diffuse source pollution

Depend on local conditions

Barrier to movement of fish and to transport of sediment Change in water regime downstream with possible consequences for water quality

Direct impacts: increased flow velocities, enhanced stream power, and higher risk of floods

Indirect impacts: reduced water storage in watersheds, reduced self-purification capacity of rivers, elimination of wetlands

Soil and river salinization resulting from irrigation

More dry conditions during the vegetation period 


\section{DROUGHTS: PROTECTION MEASURES AND RESPONSE STRATEGIES}

Droughts are long periods of abnormally low rainfall, resulting in water shortages for human activities or natural systems. According to the United Nations (UN) International Convention to Combat Desertification (ICCD) (UN 1994) definition, droughts are the naturally occurring recurrent phenomena that exist when precipitation has been significantly below normal recorded levels causing hydrological dis-balance that adversely affects land-resource production systems. They are caused by a significant reduction in the amount of precipitation, usually accompanied by high temperatures. During droughts, especially if they are accompanied by a heat wave, negative consequences for human health can occur, particularly in the developing countries.

Examples of recent drought events are: severe droughts in the African Sahel since the late 1960s; a devastating drought in southern Africa from 1991 to 1992 that threatened some 18 million people with famine; the 1999-2000 drought in Ethiopia during which more than 10 million people suffered serious food shortages; droughts in northwest Europe from 1988 to 1992 ; several droughts in the UK in the early 1990s; the 1992 drought in Brandenburg, Germany, and in Poland; the 2000-2002 drought in the Amudarya; and the 1988 and 1999 droughts in the United States (Kundzewicz and Kaczmarek 2000, Demuth 2005). Also, the heat wave of 2003 in Europe affected France, Spain, Portugal, Germany, Italy, and other central and eastern European countries. The temperatures in the summer of 2003 in Germany were on average $3.4^{\circ} \mathrm{C}$ higher than they were from 1961 to 1990 , corresponding to a recurrence period of $450 \mathrm{yr}$ (Demuth 2005).

\section{Protection Measures}

Drought protection measures range from management of water supplies to demand management of scarce freshwater resources (see examples in Table 3). Using groundwater rather than the more traditional surface reservoirs can be quite efficient despite the higher pumping costs. This is mainly because there are very high evaporation losses from surface reservoirs. Some relatively new measures such as the recycling of water, e.g., the use of treated municipal wastewater for irrigation, and the desalinization of seawater are also increasingly applied.

There are also a number of anthropogenic factors that increase potential damage by drought such as: (1) extensive agriculture that depends on irrigation, (2) land-use planning that ignores the need for water storage in watersheds, (3) overgrazing and deforestation, and (4) inappropriate land-use practices in agriculture such as black fallow between crops. Poverty is an important factor that escalates vulnerability to droughts.

\section{Response Strategies}

All measures to enhance water storage, including surface and groundwater storage across the landscape, as well as demand-side management such as developing adaptive crop-rotation practices, belong to drought-response strategies. As previously mentioned, enhanced water storage in watersheds serves to mitigate both droughts and floods. Forecast and warning systems based on risk assessment and the development of drought risk maps are also essential. During droughts and heat waves, coordinated actions involving water supply managers, farmer organizations, water users, and local authorities are needed. Because of the limited freshwater resources worldwide, which can become even more scarce under a changing climate, demand-side management is becoming more indispensable. In addition, strategies should consider social, behavioral, and political drivers within societies. Measures such as diversification, nonfarm-related livelihoods, changes in the economic structures of households and regions, and migration are of basic importance to drought vulnerability and may become even more important under climate change.

\section{CLIMATE HAZARDS IN CASE-STUDY BASINS}

\section{Case-Study Basins}

This section gives an overview of seven NeWater (EU project, contract No. 511179) case-study basins with an emphasis on climate hazards and existing response strategies. The Elbe, Guadiana, Rhine, and Tisza basins are located in Europe, the Nile and Orange are in Africa, and the Amudarya is in Central 
Table 3. Major drought protection measures.

\begin{tabular}{ll}
\hline \hline Issue & Action \\
\hline Management of water supply & $\begin{array}{l}\text { Increased water storage in surface reservoirs } \\
\text { Increased water storage in groundwater reservoirs } \\
\text { Conjunctive use of surface water and groundwater } \\
\text { Water transfer from external sources (interbasin) }\end{array}$ \\
Water reuse and water recycling \\
Desalinization of sea water \\
Management of water demand & $\begin{array}{l}\text { Improved efficiency in water use in different sectors, e.g., agriculture, } \\
\text { domestic, industrial }\end{array}$ \\
& $\begin{array}{l}\text { Improved land use in agriculture: crop substitution, modified vegetation cover } \\
\text { to reduce evapotranspiration }\end{array}$ \\
& Improved industrial practices with water-saving schemes \\
& $\begin{array}{l}\text { Development of water allocation strategies among competing demands, } \\
\text { exchange of water rights } \\
\text { Drought contingency planning: restrictions on water use, rationing schemes, } \\
\text { special water tariff, reduction in low-value uses, e.g., in agriculture } \\
\text { System of water pricing and subsidies, legal measures } \\
\text { Development of nonfarm livelihoods in drought-affected areas } \\
\text { Awareness raising, information and education on proper use of scarce water } \\
\text { resources } \\
\text { Improved monitoring and forecasting, evaluation of water supply and water } \\
\text { management using models }\end{array}$ \\
&
\end{tabular}

Asia. All seven basins are transboundary. Some major basin characteristics are presented in Table 4.

\section{The Amudarya}

The Amudarya originates in the Pamir and Hindukush mountains and stretches for about 2540 $\mathrm{km}$. Precipitation in the Amudarya basin is low, about $200 \mathrm{~mm} / \mathrm{yr}$ on average. The natural water flow is generated mainly by snow and glacial melt. The flow pattern in the downstream reaches is modified by extensive irrigation networks, diversions, and reservoirs.

\section{The Elbe}

The Elbe River basin is shared mainly between the Czech Republic upstream, which has approximately a third, and Germany downstream, which has the remainder. Compared with the Rhine, Danube, Weser, and Ems basins, the Elbe is the driest of the drainage basins in Germany because of its relatively low precipitation of about $659 \mathrm{~mm} / \mathrm{yr}$ on average.

\section{The Guadiana}

The Guadiana basin is shared between Spain (83\%) and Portugal (17\%), and it represents conditions typical of the arid climate in southern Europe. Traditionally, the main water use in the basin has been groundwater-dependent agriculture, which accounts for $90-95 \%$ of total water consumption in the upper and $88 \%$ in the lower part of the catchment, respectively.

\section{The Nile}

The Nile is the world's longest river, flowing 6700 $\mathrm{km}$ northward and joining Lake Victoria to the Mediterranean Sea. Precipitation over the basin shows a significant gradient, ranging from a maximum of about $2000 \mathrm{~mm} / \mathrm{yr}$ in the southern mountainous areas to about $200 \mathrm{~mm} / \mathrm{yr}$ in Khartoum and declining to practically zero in the desert in northern Sudan and most of Egypt. The main water withdrawals are for irrigation in agriculture, especially in the northern part of the basin.

\section{The Orange}

The Orange basin extends across large parts of South Africa, encompassing all of Lesotho and parts of Namibia and Botswana. The average annual rainfall of $2000 \mathrm{~mm} / \mathrm{yr}$ at the source decreases westward in the basin, reaching $25-50 \mathrm{~mm} / \mathrm{yr}$ in the desert regions at the mouth. 
Table 4. General characteristics of the seven river basins examined in this study.

\begin{tabular}{|c|c|c|c|c|c|}
\hline $\begin{array}{l}\text { River basin } \\
\text { (continent) }\end{array}$ & $\begin{array}{l}\text { Countries sharing drainage } \\
\text { basin }\end{array}$ & $\begin{array}{l}\text { Drainage area } \\
\left(\mathrm{km}^{2}\right)\end{array}$ & $\begin{array}{l}\text { Average annual } \\
\text { precipitation }\end{array}$ & $\begin{array}{l}\text { Flood risk? } \\
\text { Recent flood } \\
\text { events }\end{array}$ & $\begin{array}{l}\text { Drought risk? } \\
\text { Recent drought } \\
\text { events }\end{array}$ \\
\hline Amudarya (Asia) & $\begin{array}{l}\text { Uzbekistan, Tajikistan, } \\
\text { Turkmenistan, Afganistan, } \\
\text { Kyrgyz Republic }\end{array}$ & 309000 & $\begin{array}{l}200 \mathrm{~mm} / \mathrm{yr} \text { on } \\
\text { average }(50-800 \\
\mathrm{mm} / \mathrm{yr})\end{array}$ & $\begin{array}{l}\text { Yes } \\
2005\end{array}$ & $\begin{array}{l}\text { Yes } \\
2000,2001\end{array}$ \\
\hline Elbe (Europe) & $\begin{array}{l}\text { Germany, Czech Republic, } \\
\text { Austria, and Poland }\end{array}$ & 148268 & $450-1600 \mathrm{~mm} / \mathrm{yr}$ & $\begin{array}{l}\text { Yes } \\
2002\end{array}$ & $\begin{array}{l}\text { Yes } \\
2003\end{array}$ \\
\hline $\begin{array}{l}\text { Guadiana (Eur- } \\
\text { ope) }\end{array}$ & Spain, Portugal & 66800 & $400-600 \mathrm{~mm} / \mathrm{yr}$ & $\begin{array}{l}\text { Not very high } \\
1997,2004\end{array}$ & $\begin{array}{l}\text { Yes } \\
1991-1995\end{array}$ \\
\hline Nile (Africa) & $\begin{array}{l}\text { Burundi, Egypt, Eritrea, } \\
\text { Ethiopia, Kenya, Rwanda, } \\
\text { Sudan, Tanzania, Uganda, } \\
\text { Congo }\end{array}$ & 3112369 & $3-2000 \mathrm{~mm} / \mathrm{yr}$ & $\begin{array}{l}\text { Yes } \\
2002\end{array}$ & $\begin{array}{l}\text { Yes } \\
\text { Annual }\end{array}$ \\
\hline Orange (Africa) & $\begin{array}{l}\text { Lesotho, South Africa, } \\
\text { Namibia, Botswana }\end{array}$ & 896368 & $25-2000 \mathrm{~mm} / \mathrm{yr}$ & $\begin{array}{l}\text { Yes } \\
2000\end{array}$ & $\begin{array}{l}\text { Yes } \\
\text { 1991-1993 } \\
\text { Lesotho: 1994- } \\
1997\end{array}$ \\
\hline Rhine (Europe) & $\begin{array}{l}\text { Austria, Germany, France, } \\
\text { Luxembourg, Netherlands }\end{array}$ & 185000 & $700-1200 \mathrm{~mm} / \mathrm{yr}$ & $\begin{array}{l}\text { Yes } \\
1993,1995, \\
1999 \text { (Oberrhein) }\end{array}$ & $\begin{array}{l}\text { Yes } \\
\text { 2003, 2005, } 2006\end{array}$ \\
\hline Tisza (Europe) & $\begin{array}{l}\text { Ukraine, Slovakia, Hungary, } \\
\text { Romania, Serbia, Montenegro }\end{array}$ & 157218 & $500-1700 \mathrm{~mm} / \mathrm{yr}$ & $\begin{array}{l}\text { Yes } \\
2001,2005\end{array}$ & $\begin{array}{l}\text { Yes } \\
1998,2001\end{array}$ \\
\hline
\end{tabular}

\section{The Rhine}

The Rhine originates in the Swiss Alps and flows through Austria, Germany, France, Luxembourg, and the Netherlands. Annual precipitation in the Rhine basin varies from 700 to $1200 \mathrm{~mm}$. The Rhine is one of the world's most intensively navigated inland waterways, and its water is used to irrigate areas of intensive agriculture and vineyards, which produce wines of a high quality. Over the last two centuries, the basin has lost more than $85 \%$ of its natural alluvial areas because of human use for settlements and agriculture (Moyen 1998).

\section{The Tisza}

The Tisza River is one of the largest tributaries of the Danube. The basin covers parts of Ukraine, Slovakia, Hungary, Romania, Serbia, and Montenegro. Climatic conditions in the basin are moderately continental, and water from the Tisza is used for crop irrigation, for household water supplies, to provide hydropower, by industry and fisheries, and for recreation.

\section{Climate Change Observed and Projected}

The observed climate trends and projected climate scenarios for the seven basins are outlined in Table 5. Differences in average annual precipitation between the scenario period of 2041-2060 and the reference period 1961-2000 according to the General Circulation Models (GCMs) HadCM3 and ECHAM4 for all seven basins are shown in Figs. 1 and 2 (resolution $0.5^{\circ}$ ).

Table $5 \mathrm{~A}$ and the figures show that the climate tends to become warmer in all basins, but precipitation trends are different: There is a mostly upward trend 
Table 5. Observed trends in climate and projected climate scenarios for six of the seven basins studied. The Nile, which runs through 10 countries, was not included because of insufficient data.

Table 5A. Indicators of climate change trends.

\begin{tabular}{|c|c|c|c|}
\hline River basin & Observed temperature trends & Observed precipitation trends & $\begin{array}{l}\text { Observed snow and glacier } \\
\text { dynamics }\end{array}$ \\
\hline Amudarya & $\begin{array}{l}\text { Upper catchment }{ }^{\dagger} \text { (Tajikistan): } \\
\text { temperature increases of } 0.7- \\
1.2^{\circ} \mathrm{C} \text { in the valleys, } 0.1-0.7^{\circ} \mathrm{C} \\
\text { at high altitudes } \\
\text { Lower catchment } \\
\text { (Turkmenistan): small increase } \\
\text { of about } 0.5^{\circ} \mathrm{C}\end{array}$ & $\begin{array}{l}\text { Seasonal redistribution of } \\
\text { precipitation, mostly an increase } \\
\text { at higher altitudes, increase in } \\
\text { extremes at lower altitudes } \\
\text { Change in type of precipitation } \\
\text { (hard vs. liquid) }\end{array}$ & $\begin{array}{l}\text { Glacier degradation: } 14 \% \\
\text { decrease from } 1957 \text { to } 1980^{\S} \\
\text { Snow stock }{ }^{\dagger}: 35 \% \text { increase on } \\
\text { average at altitudes up to } 2000 \mathrm{~m} \text {, } \\
35 \% \text { decrease at altitudes of } \\
2000-3500 \mathrm{~m} \text { (not in all regions) }\end{array}$ \\
\hline Elbe (German part) & $\begin{array}{l}1.1^{\circ} \mathrm{C} \text { increase in temperature } \\
\text { during the last } 50 \mathrm{yr}^{\dagger}\end{array}$ & $\begin{array}{l}46 \mathrm{~mm} \text { decrease in summer } \\
\text { precipitation, } 50 \mathrm{~mm} \text { increase in } \\
\text { winter precipitation during the } \\
\text { last } 50 \mathrm{yr}\end{array}$ & No observations \\
\hline Guadiana & $\begin{array}{l}\text { Average maximum temperatures } \\
\text { stable in the upper basin } \\
\text { Average temperatures increased } \\
\text { by } 1.8^{\circ} \mathrm{C} \text { from } 1950-1975 \text { to } \\
1975-2002\end{array}$ & $\begin{array}{l}7 \% \text { decrease in the last two } \\
\text { decades over the period } 1950- \\
2002 \text { in the upper basin }\end{array}$ & Not applicable \\
\hline Orange & $\begin{array}{l}\text { South Africa: average } \\
\text { temperature increase of } 0.2^{\circ} \mathrm{C} \\
\text { during } 1990 \mathrm{~s}^{\#} \text { Namibia: increase } \\
\text { of } 1.15^{\circ} \mathrm{C} \text { between } 1950 \text { and } \\
2000^{\dagger \dagger} \text { Botswana: increasing } \\
\text { trend of about } 1^{\circ} \mathrm{C} \text { over period } \\
1900-1990^{\ddagger \ddagger}\end{array}$ & $\begin{array}{l}\text { South Africa, Botswana: no } \\
\text { overall trend } d^{\dagger \dagger,+\neq} \text { Namibia: } \\
\text { extremely high variation in } \\
\text { rainfall in excess of } 30 \% \text { across } \\
\text { country, rising to } 70 \% \text { in } \\
\text { southern areas }\end{array}$ & $\begin{array}{l}\text { Snow is common in the Lesotho } \\
\text { portion of the basin, but data not } \\
\text { accessible }\end{array}$ \\
\hline Rhine & $\begin{array}{l}1^{\circ} \mathrm{C} \text { temperature increase during } \\
\text { the last century }\end{array}$ & $\begin{array}{l}\text { During the 20th century, winter } \\
\text { precipitation has increased by } \\
\text { about } 10-20 \% \text {. No significant } \\
\text { trend in summer precipitation } \\
\text { detected }^{\S \S}\end{array}$ & $\begin{array}{l}\text { Switzerland: since } 1850 \text { the } \\
\text { surface covered by glaciers has } \\
\text { decreased from } 1800 \text { to } 1300 \\
\mathrm{~km}^{2} \text {. The volume has decreased } \\
\text { from } 107 \text { to } 74 \mathrm{~km}^{3 \|}\end{array}$ \\
\hline Tisza & $\begin{array}{l}\text { Temperature increase of about } \\
1^{\circ} \mathrm{C} \text { during the last } 50 \mathrm{yr}^{|l| l \mid}\end{array}$ & $\begin{array}{l}\text { Upward trend in precipitation in } \\
\text { Ukrainian part } \\
\text { Downward trend in precipitation } \\
\text { in Hungarian part }\end{array}$ & $\begin{array}{l}\text { No glacier environments in the } \\
\text { basin }\end{array}$ \\
\hline
\end{tabular}

Table 5B. Projected climate scenarios for these basins.

\begin{tabular}{|c|c|c|}
\hline River basin & Change in temperature & Change in precipitation \\
\hline Amudarya & $\begin{array}{l}\text { Upper catchment }{ }^{\dagger} \text { : increase of } 1.8-2.9^{\circ} \mathrm{C} \text { by } \\
2050 \text { Lower catchment }+ \text { increase of } 1-2^{\circ} \mathrm{C} \\
\text { by } 2030 \\
\text { Increase in temperature extremes. }\end{array}$ & $\begin{array}{l}\text { Both an increase }(3 \%-26 \%) \text { and a decrease } \\
(3 \%-5 \%) \text { are projected by different models } \\
\text { by } 2050 \\
\text { Change in distribution of precipitation. }\end{array}$ \\
\hline Elbe (German part) & $\begin{array}{l}\text { Increase of } 1.5^{\circ} \mathrm{C} \text { by } 2051-2055 \text { compared } \\
\text { with } 1961-1990 \text { (model STAR) }\end{array}$ & $\begin{array}{l}\text { Small decrease of } 5.6 \mathrm{~mm} \text { according to } \\
\text { model STAR by } 2051-2055 \text { compared with } \\
\text { 1961-1990 }\end{array}$ \\
\hline
\end{tabular}


Guadiana

Orange

Rhine
Worst case scenario: increase of $1-2^{\circ} \mathrm{C}$ in winter and $4-5^{\circ} \mathrm{C}$ in summer by $2070^{\dagger \dagger}$

South Africa: average increase of $2.5-3^{\circ} \mathrm{C}$ over north-central parts by $2050^{\S \S}$ Namibia: $2-6^{\circ} \mathrm{C}$ above $1961-1990$ mean by $2100^{\dagger}$ Lesotho: $1.2-4.4^{\circ} \mathrm{C}$ increase by $2075^{\ddagger}$ Botswana: $1-3^{\circ} \mathrm{C}$ increase by $2050^{\circ *}$

Increase of $1.0-2.0^{\circ} \mathrm{C}$ by $2050^{\mathrm{II}}$

Increase of $0.7-2.5^{\circ} \mathrm{C}$ by $2050^{\text {qIIIII }}$
Worst case scenario: decrease up to 0.25 $\mathrm{mm} / \mathrm{d}$ in winter and $0.5 \mathrm{~mm} / \mathrm{d}$ in summer by $2070^{\dagger \dagger \dagger}$

South Africa, Lesotho, Botswana: Different models project increases up to $5 \%-10 \%$ and decreases up to $10 \%-25 \%$. ${ }^{8}$, , Namibia: decrease of up to $200 \mathrm{~mm} / \mathrm{yr}$ less than current average

Increase of about $14 \%$ in winter precipitation by 2050 , depending on temperature increase ${ }^{\| l \mid}$

Increase of up to $30 \%$ in the Carpathians Decrease of $\sim 10 \%-30 \%$ in the spring period in Hungary and Ukraine by $2050^{\text {TITIT }}$

Republic of Tajikistan (2002)

*MNPT (1999)

${ }^{\S}$ Dukhovny (2002)

Hattermann et al., (2006)

"Martínez-Santos et al. (2004)

\#Department of Environmental Affairs and Tourism (1999)

†Tarr (2002)

挢MWCB (2001)

$\$ \S$ Klein Tank (2004)

"Maisch et al. (1997)

IIIIIPCC (2007)

\#\#Jolonkai and Pataki (2005)

MMA (2005)

Ministry of Natural Resources (2000)

$\S \S \S$ Turpie et al. (2002)

${ }^{\prime \mid}$ Hurk et al. (2006)

MIIIII MPI (2006)

for the Nile and Rhine, a downward trend for the Guadiana, and varying subareal and seasonal trends for the Amudarya, Elbe, Orange, and Tisza. It is worth mentioning that the differences between the scenarios for the two models, e.g., for precipitation in the Amudarya basin (Fig. 2), are mainly because of the inherent model uncertainty in current GCMs.

A large-scale glacier degradation is taking place in the Amudarya basin: Small glaciers are disappearing, and large glaciers are shrinking. The glacial area in the Amudarya basin has shrunk $13.1 \%$ from 1957 to 1980 , i.e., from 7144 to 6205 $\mathrm{km}^{2}$ (Agaltseva 2005).

Climate change may also alter the timing and magnitude of runoff peaks, as well as the relative runoff contributions from rain, snow, and glacier melt. This will affect the flow patterns of the rivers.
For example, the climate change impact assessment for the Elbe shows that even a relatively small decrease in precipitation coupled with higher temperatures can result in a significant decrease in groundwater recharge and seasonal river flow (Hattermann et al. 2006).

In general, the risk of extreme climatic events is expected to increase under warmer temperatures. Flood frequency and magnitude will probably increase in regions that experience increases in precipitation, whereas drought frequency will increase in regions that experience a reduction in precipitation. For example, the report from the EEA (2004) warns of increasing drought frequency in the southern areas of the Iberian Peninsula, an increased risk of forest fires, widespread heat waves, and consequent risks for human health. It is also likely that the frequency of intense precipitation, and 
Fig. 1. Difference in average annual precipitation between scenario period 2041-2060 and reference period 1961-2000 as seen in climate models HadCM3 and ECHAM4 (resolution 0.5 ${ }^{\circ}$ ). The basins are the Rhine, Elbe, Tisza, and Guadiana, and the lines define catchment boundaries.

\section{HadCM}

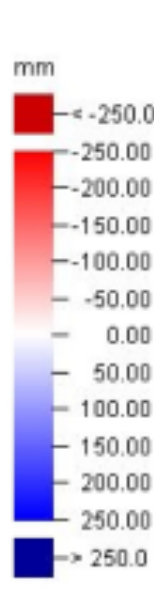

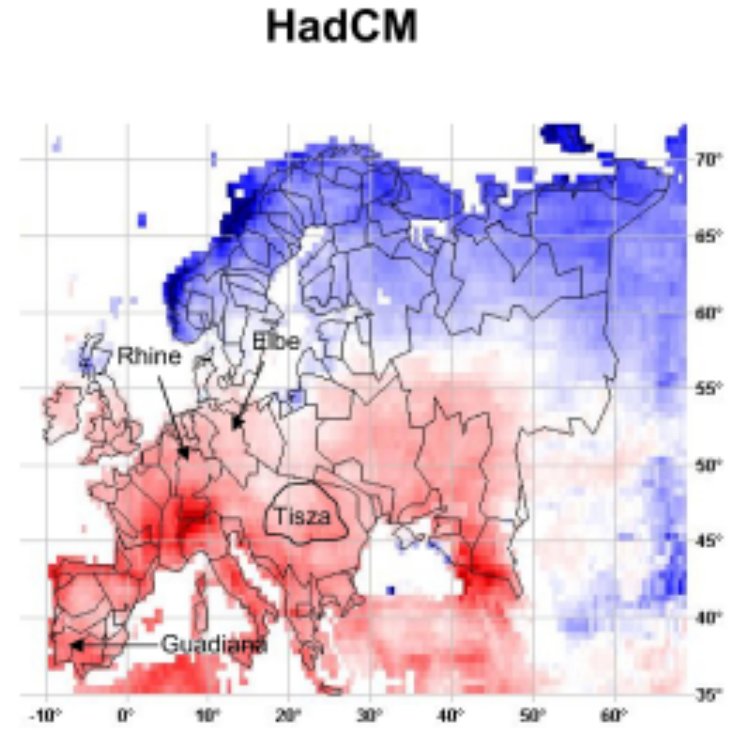

ECHAM

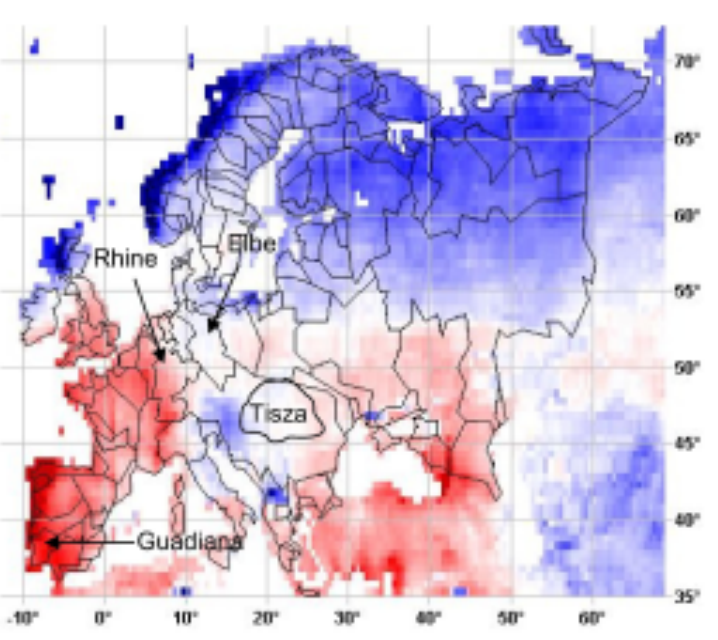

hence flooding events, will increase in Europe (Parry 2000), although uncertainties remain high.

\section{Climatic Hazards in the Basins}

\section{The Amudarya}

People who live in the Amudarya basin often experience droughts and floods. The severe drought during 2000 and 2001 caused significant crop losses and shortages of drinking water. The last significant flood in 2005 caused damage to settlements and the irrigation infrastructure. In low-water years, the region operates in a water deficit regime, and thus it is very vulnerable to a potential decrease in water availability in future.

Climate change could substantially affect the water resources of the Amudarya if precipitation decreased. Climate change will alter the relative runoff contributions from snow, glacier melt, and rain, which are currently $78 \%$ from snow and 14\%-
$16 \%$ from glacier melt (Ososkova et al. 2000). As the glacier melts, its contribution to runoff in the future will be reduced. Because of glacier degradation, it is expected that the total runoff of the Amudarya will be reduced by $3 \%$ before 2020 , by $6 \%$ before 2030 , and by $15 \%$ before $2050-2075$ (Agaltseva 2005). Changes in the hydrological regime will influence current rules for operational regimes of reservoirs and water availability for various water users. Flooding could cause mudslides and the breaking of natural dams on mountain lakes in the upstream areas, and could subsequently pose serious threats across the entire basin. However, at present, there is high uncertainty regarding the direction of change in precipitation in the basin (see HadCM and ECHAM scenarios in Fig. 2).

\section{The Elbe}

The Elbe River is experiencing all three major water-related problems: too much water once in a while, i.e., floods; too little water from time to time, 
Fig. 2. Difference in average annual precipitation between scenario period 2041-2060 and reference period 1961-2000 as seen in climate models HadCM3 and ECHAM4 (resolution 0.5 ${ }^{\circ}$ ) The basins are the Amudarya, Nile, and Orange, and the lines define catchment boundaries.
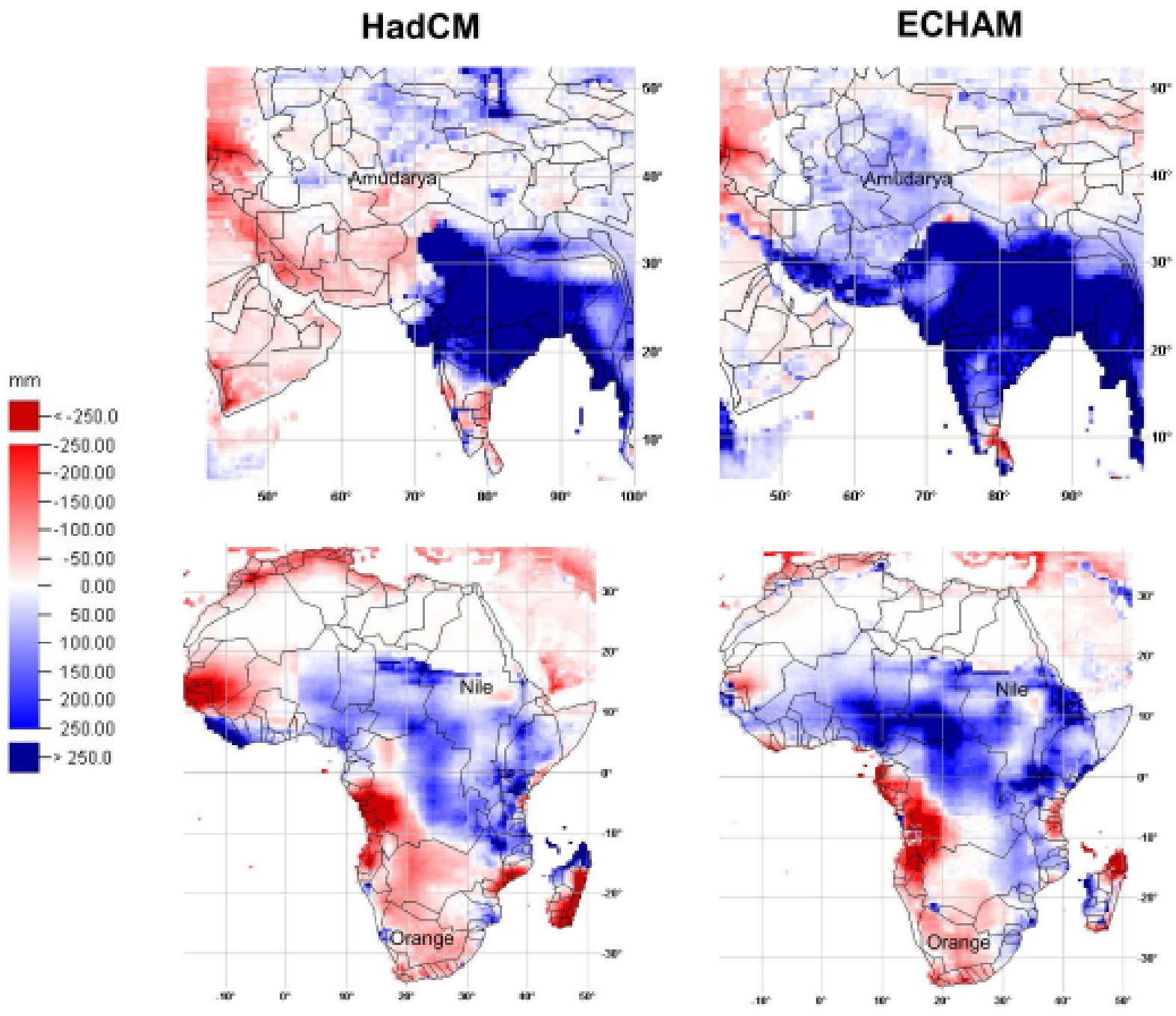

i.e., droughts; and water of inadequate quality, although a notable improvement in water quality was achieved over the last 15 yr (Krysanova et al. 2006). Recently, extreme hydrological events were observed in the basin. There was a destructive flood in August 2002, followed by a severe drought in 2003. Because of the disastrous flood in 2002 , general public attention has strongly shifted to the flooding problem. Statistically significant trends in dry indices were found for the lowland part of the basin (Krysanova et al. 2008).

Higher average temperatures and lower precipitation in the summer months are projected for the basin under future climatic conditions. Thus, the water scarcity problem in this densely populated area will 
likely grow, and the risk of droughts will increase; this will possibly have adverse consequences on several sectors, including water supply, agriculture, forestry, navigation, and recreation. On the other hand, the intensity of rainfall and the frequency of floods are expected to increase under climate change (Becker and Grunewald 2003).

\section{The Guadiana}

Water use in the Guadiana basin is heavily conditioning the agricultural sector, which is likely to suffer the most from the potential effects of climate change. Floods are not a particular issue of concern, given climatic conditions and the considerable absorption capacity of depleted aquifers and reservoirs. Droughts are of importance for rain-fed agriculture, but currently not for the irrigated agriculture.

The report from the EEA (2004) suggests that Spain and Portugal are likely to be the EU member states most affected by climate change. The EEA warns of the consequences of climate change, e.g., increased drought frequency in southern Spain, more forest fires, widespread heat waves, and further risks for human health.

\section{The Nile}

Population density, local water availability, and the demand for water for irrigation determine levels of freshwater scarcity, desertification, and land degradation in different parts of the Nile basin. Ethiopia suffers from recurrent drought, and the 1984-1985 famine known as "War and drought" caused a food crisis during which about a million people died. Ethiopia has never fully recovered from this disaster. Widespread flooding throughout Kenya in 2002 occurred in seven of Kenya's eight provinces. A total of 175000 people were affected, up to 60000 people were displaced, and 50 people were reported dead.

There is evidence of ongoing climatic change in the Nile basin. Simulations by GCMs show a fairly uniform increase in temperature across the basin, and varying changes in precipitation, which generally increase in the southern part of the basin (Fig. 2).

\section{The Orange}

Water is a limiting resource for development in the Orange basin. During the past $20 \mathrm{yr}$, most of Africa has experienced extensive droughts, and the last two in 1986-1988 and 1991-1992 were attributed to El Niño. In 2000, South Africa experienced a severe flood, which caused extreme damage to roads, infrastructure, agricultural crops, and property (Du Plessis 2002).

Changes in water supply could have major implications for most sectors of the economy, especially agriculture. Schulze et al. (2005) published an extensive review about climate change in South Africa, projecting a decrease in mean annual precipitation of approximately $15 \%-25 \%$ in the western portion of the basin, and an increase of up to $10 \%$ in the upper regions by 2100 (Fig. 2). An increase in the number of rainless days is projected, and the number of days with heavy precipitation will also increase, exacerbating flood events.

\section{The Rhine}

In recent years, people in the Rhine basin have been confronted on several occasions with water-related problems caused by high water levels in 1993 and 1995 and by excessive rainfall in 1993, 1994, and 1998. Extreme droughts, e.g., in 2003, are also increasingly drawing the attention of water managers.

The GCMs project an increase in temperature of 2$4^{\circ} \mathrm{C}$ and an increase in winter precipitation of about $20 \%$ for the Rhine basin by the end of the $21 \mathrm{st}$ century. Rainfall will increase throughout the year, causing an increase in flood frequency. However, higher summer temperatures will increase evapotranspiration; thus paradoxically, less water will be available in the summer, causing a greater risk of droughts and heat waves.

\section{The Tisza}

The frequency of extreme floods in the Tisza basin has increased sharply from once every $18 \mathrm{yr}$ in 1877-1933 to once every 3-4 yr in 1934-1964, and to almost once every other year over the last decade.

For the lowland part of the basin, a downward trend in annual precipitation has been detected (Jolonkai and Pataki 2005) and projected (Fig. 1). In the Carpathians, precipitation is expected to increase by up to $30 \%$ before 2050, except in the spring (MaxPlanck-Institut for Meteorology, unpublished data). 


\section{STRATEGIES FOR COPING WITH CLIMATIC HAZARDS}

\section{The Amudarya}

Over the centuries, water management strategies and policies have been developed in the Amudarya basin to allocate water resources for various uses, including irrigation. Specific concepts and mechanisms to deal with droughts and floods are available in the basin. Over the past decades, a strong emphasis has been placed on technical measures to cope with the high variability of water availability. Current measures for coping with droughts and floods include:

- two single-year storage reservoirs, smallscale reservoirs in the wetlands of the river delta, and the use of former bays of the Aral Sea for water storage;

- water-allocation planning measures, e.g., reduction of allocation quotas to all regions by fixed percentages when a low-water year is forecast;

- water-saving technologies related to irrigation to decrease water demand in agriculture and increase efficiency;

- the establishment of a transboundary flood emergency committee to ensure quick responses to flood risks; and

- campaigns to raise awareness among water users about water conservation and flood protection.

However, recent extreme events have revealed that existing measures may be insufficient and may fail to mitigate extreme situations in the future, especially in the downstream areas. Single-year reservoirs have only a limited potential for drought mitigation. The deteriorating infrastructure, caused by the lack of maintenance and investments over the past $20 \mathrm{yr}$, aggravates the situation. Moreover, current socioeconomic problems in the basin, which are related to the political transition after the breakup of the Soviet Union, appear to be much more relevant for decision makers than is the expected impact of climate change. The latter is seen within the context of a general need to reduce pressure on water resources and cope with water deficits in low-water years, especially in the lowland countries of Uzbekistan and Turkmenistan. It is believed that the challenges of climate change can be met merely by better water management and a more rational use of water resources. However, the development of adequate financial and legal incentives to save water is urgently needed, although such measures are difficult to implement. Moreover, transboundary cooperation is essential for the development of coping strategies.

\section{The Elbe}

The need to develop a proper flood management strategy in the basin is recognized. Two main elements of flood risk management are the reduction of flood risk and coping with floods. Preventive measures against flooding (German Committee for Disaster Reduction (DKKV) 2004) combine engineering facilities, river-basin planning, and financial and social measures. These include:

- technical flood protection, including facilities for water retention such as dams, storage reservoirs, and polders;

- river-basin planning to increase natural water retention in catchment areas;

- $\quad$ spatial planning to keep new construction out of floodplains as far as possible;

- construction measures to ensure that buildings in flood-prone areas are appropriately constructed;

- $\quad$ risk-spreading methods, including financial provisions backed by insurance;

- behavioral or social measures that explain, prepare for, and practice ways to cope with dangerous flood-related situations; and

- informational measures such as flood alarms and warning systems.

Above all, coping with flood disasters means help for flood victims, averting disastrous impacts of flooding, and help in reconstruction.

Measures used in water management, which are especially needed during periods of drought, are water-saving technologies, water price mechanisms, and optimization of water-resource use. In the 
future, other measures such as land-cover change and the introduction of new crop varieties could be needed under a drier climate, and measures such as water-saving technologies and optimization of water use will need to be enforced.

\section{The Guadiana}

Although specific strategies have not yet been drafted for the Guadiana basin, the report on climate change from Spain's Ministry for the Environment already displays a series of adaptive alternatives for the entire country (Ministry for the Environment 2005), which includes three main lines of action:

- demand management solutions based mostly on water pricing, legal measures, waterefficient cropping patterns, public information, and education;

- enhanced water management, including improvements in monitoring networks, management models, and databases, and the creation of centers for exchange of water rights; and

- $\quad$ supply-based solutions such as increasing storage capacity, water transfers from wet subregions, groundwater development, water harvesting, afforestation, water reuse, and desalination.

Whereas the first two sets of measures can be looked upon with optimism, it is clear that opportunities to implement the third set of solutions in the Guadiana basin are limited. The middle and lower reaches of the catchment already boast two of Europe's five largest reservoirs, i.e., the Alqueva and La Serena, whereas intensive groundwater use is commonplace in the upper part of the basin. Also, because economic constraints probably exclude desalination in the continental areas, existing interbasin transfers, water reuse, and afforestation remain the only alternatives that could be developed further.

It is precisely in the upper part of the basin where the main lessons could be learned about how to cope with droughts. A drought-prone region, the Upper Guadiana basin $\left(16000 \mathrm{~km}^{2}\right)$ is underlain by aquifer formations whose saturated depth often exceeds 300 $\mathrm{m}$. Estimated groundwater storage exceeds 15000 million $\mathrm{m}^{3}$, whereas annual renewable resources amount to 200-400 million $\mathrm{m}^{3} / \mathrm{yr}$. Such a large capacity makes this aquifer system similar to a macroreservoir, although without the huge evaporation losses that a surface reservoir usually experiences.

As the events in the early 1980s and 1990s show, the aquifers are able to withstand several years of severe drought in exchange for fairly small increases in pumping costs, even if the total irrigated surface exceeds 200000 ha and accounts for more than $90 \%$ of the area's water uses. A further advantage is that individual well owners may access groundwater on demand, which is essential for such a time-critical activity as irrigation. This means that groundwater-based farmers tend to experience increased revenues during drought periods because of the negative impact that these have on rainfed and surface-water-irrigated agriculture (Llamas and Martínez-Santos 2005).

Therefore, the Upper Guadiana basin offers a remarkable example of drought proofing through intensive groundwater development. However, this has its environmental costs, because some groundwater-dependent ecosystems have been lost because of water-table depletion. Making irrigation and wetland conservation compatible under more severe climate conditions remains the main challenge for the future.

\section{The Nile}

Coping with climate extremes in such a large basin is an extremely complex issue. Here it will be only briefly outlined using the example of Kenya (Mathur et al. 2004). The Kenyan government is undertaking reforms of the water sector that have the potential to improve the management of extreme events in future. This improved management can be grouped under three headings: improved prediction, improved protection, and response. Improved prediction requires data acquisition, flood forecast modeling based on available climate scenarios, and early warning systems.

Improved protection includes repairing and developing the infrastructure needed to contain floodwater and provide surface and subsurface storage for drought periods; regular monitoring and evaluation of groundwater levels, water discharge, and water quality; the establishment and enforcement of standards; and the development of groundwater programs based on known recharge 
rates. Kenya has the potential to develop conjunctive uses of surface and groundwater so that water from periods of excess flows can be stored in aquifers for use during dry periods. A new land-use policy is being developed that is likely to include the prohibition of certain land uses in flood-prone areas.

The response to floods and droughts is partly based on the country's predictive capability. With sufficient time and certainty, people and livestock can be moved from endangered areas before the event occurs. Similarly, short-term emergency responses such as the provision of food and medical assistance can be optimized with sufficient advanced warning and coordination between the government and private sectors.

\section{The Orange}

Current water management policies and mechanisms have been developed to ensure that the existing supply of water meets the growing demand. Some of these may be appropriate for dealing with future water shortages under climate change, but robust long-term strategies are required to ensure that the demand for water matches the supply in times of reduced availability.

Regarding flood protection, the emphasis was until recently still on structural mitigation measures, and little attention was given to hazard and risk assessment for different river reaches (Du Plessis 2002). Recently, three basic areas of adaptation have been suggested for the basin (Benioff et al. 1996, Mukheibir and Sparks 2003):

- increased water supply, including the construction of reservoirs and dams, the development of groundwater resources, the use of interbasin transfers, and the modification of vegetation cover to reduce evaporation;

- demand-side management, water reuse, and water recycling; and

- different ways of managing supply and demand, e.g., crop substitution, conjunctive use of groundwater and surface water, better climate forecasting, more versatile interbasin transfer schemes, and more flexible operating rules for water systems.
The National Disaster Management Centre of South Africa has established a number of working groups to prepare components of the National Disaster Management Framework. Flood management policy will include proposals for guidelines and institutional responsibility with regard to the optimization of the operation of large dams, sustainable use of floodplains, design criteria for infrastructure situated on or adjacent to rivers, effective flood warning systems combined with programs for public and institutional education, and training and awareness creation.

\section{The Rhine}

The traditional strategy for water management in the Rhine basin was based on controlling water. Over the centuries, the dikes that defended reclaimed land were built and strengthened, and the river reaches were straightened and widened to allow water to be speedily discharged to the sea. This approach provided a relatively high safety standard compared with that of many other countries. However, after the floods in the 1990s, the International Commission for the Protection of the Rhine acknowledged that the existing strategy was no longer sufficient to maintain safety standards in view of the changing climate.

The new international Action Plan on Floods Defense (International Commission for the Protection of the Rhine (ICPR) 1998) aims at the improvement of precautionary flood protection, for which five guiding principles are formulated:

1. Water is part of the whole and must be given due consideration in all policy fields.

2. Water should be stored and retained as long as possible in the catchment.

3. The river should be allowed to expand so that it has enough room to delay runoff and reduce danger.

4. Water managers and the public should be aware of the danger, because there will always be a certain risk.

5. Integrated and concerted action in the basin is a prerequisite for successful management. 
Based on these principles, four major targets were postulated: to reduce flood stages, to reduce the risk of damage, to increase awareness of flood risk, and to improve the system of flood forecasting. The national strategies in Germany and the Netherlands are built in agreement with this plan.

The Dutch strategy is based on minimizing the consequences of flooding, and the new paradigm in water management is "learning to live with the floods." The country is creating a flexible system that can deal with unpredictable events and be adapted to cope with future development. To reduce flood damage caused by excessive rainfall, the new mantra is: "First retain water, then store, and only then discharge." Land along rivers will be set aside to widen floodplains and create retention basins for incidental inundation. These areas can still have multifunctional uses, e.g., for agriculture or recreation. Parts of polders will be designated as emergency storage areas. This should not only reduce the flood risk by reducing high water levels in canals and rivers, but also mitigate the effects of droughts in summer and reverse the degradation of nature caused by overdrainage. However, several studies have shown that, at the scale of the entire Rhine basin, land-use changes alone cannot compensate for the impact of climate change (Middelkoop et al. 2004). Thus, traditional structural measures should be maintained and updated. Also, strengthening of the present defenses against the effect of rising sea levels is planned in coastal areas.

Similar developments are taking place in Germany, where an action plan was initiated that covers five main issues: assessment of historical trends in climate and water, impact assessment of potential climate change on water resources, enhanced monitoring programs, the development of sustainable provision concepts for water management policy, and distribution of results to the scientific community and public (Klimaveränderung und Wasserwirtschaft (KLIWA) 2006).

It is acknowledged that the effects of new management strategies in both countries can be further optimized if they are applied to the whole basin with improved cross-border cooperation.

\section{The Tisza}

In the past, both Hungary and Ukraine shared a common policy of using traditional measures to cope with emerging floods. In Hungary, extensive hydroengineering constructions were built in the 19th century to limit the dimension of inundation and increase flood safety. The floodplain area was drastically reduced by the construction of dikes, levees, and bank-protecting structures. The Tisza was shortened by about $400 \mathrm{~km}$ and deepened to facilitate transport. Currently, some 500000 people live on land reclaimed from the floodplains. The rising water levels of floods have been typically addressed by increasing the crowning levels of the dikes and reinforcing protective structures. In the Upper Tisza basin in Ukraine, the flood defense system also consists mainly of dikes $(707 \mathrm{~km})$, embankments, and $260 \mathrm{~km}$ of bank-protecting structures. Measures of protection against drought are nearly nonexistent in the basin.

This technical protection scheme appeared to be successful until the record-breaking floods of 2001 and 2005, which caused an enormous amount of damage because of several dike breaches. As a result, alternative solutions such as small emergency reservoirs and polders and integrated land-use management within the floodplain are gaining more attention in both countries (Horvath et al. 2001).

Nevertheless, the new Hungarian Vásárhelyi Plan (Vásárhelyi Plan Intersectorial Committee 2004) addressing water management in the Tisza basin aims to solve the flood-protection problem almost exclusively by building six new emergency reservoirs and leaving other options for the future. Public awareness and collaboration with NGOs that criticized this exclusively technical strategy have helped to broaden the aims of the plan, which now include some novel solutions such as agroecological farming practices, ecotourism, and nature conservation (Burnod-Requia 2004). One lesson learned in the basin is that public awareness is helpful for improving water management.

The same or similar strategies exist for the Ukrainian part of the basin. There are also several international and bilateral agreements aimed in fostering and strengthening collaboration for flood protection. 


\section{COMPARATIVE ANALYSIS OF STRATEGIES AND LESSONS LEARNED}

The coping strategies in these case-study basins can be compared by analyzing information about existing measures and the need for their improvement, as described above and summarized in Tables 6 and 7. Such a comparison is of course not easy and is possible only to a limited extent because of differences in environmental and climatic conditions, the scales of the basins, and the institutional context, i.e., what is effective in one basin might not work in another. First, different types of measures will be compared for the seven basins, and then their commonalities and differences and some unique examples of solving water-management problems will be listed.

\section{Structural Measures}

Structural measures for flood protection, e.g., dams, dikes, etc., exist in all river basins. Dams are designed for flood security, and reservoirs serve for water storage. All structural engineering constructions must be maintained and updated, although it may be hard to do this because of conflicting interests. The largest uncertainty related to climate change is whether dams designed using historical data will be able to withstand more intensive floods, which are possible under changed climatic conditions. It is very difficult to understand and accurately predict the effect of climate change because of the many uncertainties involved, including the natural variability of hydrological systems, the fact that relevant data have been collected for only short periods, and the restricted capabilities of climatic and hydrological models for predictions (Beven 2000). Some of the related uncertainties can be reduced, whereas others are unavoidable.

\section{Nonstructural Measures}

Some of the nonstructural measures in watersheds are also implemented in river basins, but they are mostly limited in extent. Increasing natural water retention is stated as necessary in the Elbe, Rhine, Tisza, and Amudarya. Improved land-use schemes and new land-use policies are needed for the Nile and Orange. Although the need for such measures seems to be well understood, sometimes even newly developed management plans do not include them, e.g., the Vásárhelyi Plan for managing the Tisza.

\section{Social Measures}

Social measures such as advanced alarm and warning systems, household mitigation actions, increased awareness, and education are ongoing for the Rhine, Elbe, Guadiana, and Tisza, but there are few such measures for the Amudarya and Orange. Measures related to behavioral drivers such as diversification, nonfarm livelihoods, migration, and changes in the economic structures of households and regions are especially important for basins that struggle with severe droughts, e.g., the Nile, Orange, and Amudarya, because these drought periods may become even more dramatic in the future. Improvements in social and behavioral measures and their extension to include community emergency planning and household actions are needed for all the basins. The aim here should be to provide a wide spectrum of social measures, learning from those basins that have more advanced levels of implementation.

\section{Supply-side Measures}

Supply-side measures for drought protection, e.g., surface and groundwater reservoirs and watertransfer schemes, exist almost everywhere. The need for improvement includes increasing storage potential (the Orange), protection of groundwater aquifers (the Guadiana), and improvement of the conjunctive use of surface water and groundwater (the Nile). In some basins, e.g., the Amudarya and Guadiana, there are not many options for improvement on the supply side.

\section{Demand-side Measures}

Demand-side measures are quite well developed in the Elbe, Rhine, and Guadiana. These measures still need improvement for all basins, including better irrigation schemes in the Orange, control of illegal water extraction in the Guadiana, and water-saving and optimization measures in the Amudarya. Learning from those basins that have more experience is also recommended, taking into consideration differences in scale and institutional context. 
Table 6. Existing measures for coping with floods and droughts in six of the seven basins studied. The Nile, which runs through 10 countries, was not included because of insufficient data.

Table 6A. Flood control measures.

\begin{tabular}{|c|c|c|c|}
\hline River basin & Structural measures & Nonstructural measures & Social measures \\
\hline Amudarya & $\begin{array}{l}\text { Two major reservoirs } \\
\text { Overflow structures } \\
\text { Water storage in wetlands } \\
\text { and polders }\end{array}$ & $\begin{array}{l}\text { Use of former lakes, } \\
\text { depressions, and bays of Aral } \\
\text { Sea for water storage }\end{array}$ & $\begin{array}{l}\text { Bilateral Turkministan and } \\
\text { Uzbekistan flood emergency } \\
\text { committee in the delta region }\end{array}$ \\
\hline Elbe & $\begin{array}{l}\text { Water storage reservoirs } \\
\text { Dams } \\
\text { Dikes } \\
\text { Polders }\end{array}$ & $\begin{array}{l}\text { River basin planning now } \\
\text { includes measures to increase } \\
\text { natural water retention areas } \\
\text { and keep construction out of } \\
\text { floodplains }\end{array}$ & $\begin{array}{l}\text { Flood alarm and warning } \\
\text { systems } \\
\text { Flood preparedness by } \\
\text { distribution of information } \\
\text { and education }\end{array}$ \\
\hline Guadiana & $\begin{array}{l}\text { Water storage reservoirs } \\
\text { Emergency channels }\end{array}$ & $\begin{array}{l}\text { Soil conservation and } \\
\text { afforestation measures } \\
\text { Drainage networks along } \\
\text { streets and roads }\end{array}$ & $\begin{array}{l}\text { Public information and } \\
\text { education }\end{array}$ \\
\hline Orange & $\begin{array}{l}\text { Several very large dams } \\
\text { designed partly for water } \\
\text { security }\end{array}$ & $\begin{array}{l}\text { Poorly developed because } \\
\text { there are few floodplains, } \\
\text { however, Johannesburg with } \\
\text { its largely informal shanty } \\
\text { towns presents a perennial } \\
\text { flooding problem }\end{array}$ & $\begin{array}{l}\text { Ongoing and largely } \\
\text { unsuccessful attempts to } \\
\text { prevent settlement in } \\
\text { floodplains, mainly in } \\
\text { Johannesburg }\end{array}$ \\
\hline Rhine & $\begin{array}{l}\text { Reinforcement of dikes } \\
\text { Retention polders } \\
\text { Lowering of floodplains } \\
\text { Reactivation of old river } \\
\text { branches }\end{array}$ & Land-use planning & $\begin{array}{l}\text { Flood action plan: raising } \\
\text { awareness by flood risk maps } \\
\text { and other publicity measures }\end{array}$ \\
\hline Tisza & $\begin{array}{l}\text { Dams } \\
\text { Dikes } \\
\text { Six emergency reservoirs/ } \\
\text { polders under construction } \\
\text { along the upper and middle } \\
\text { Tisza sections } \\
\text { Flood/riverbed cleaning for } \\
\text { conveying flow capacity }\end{array}$ & $\begin{array}{l}\text { Integrated land-use planning } \\
\text { in the floodplains according } \\
\text { to the new "Vásárhelyi Plan" } \\
\text { Reforestation programs in } \\
\text { Zacarpathian part started }\end{array}$ & $\begin{array}{l}\text { Flood vulnerability and risk } \\
\text { surveys } \\
\text { National program of payment } \\
\text { after floods } \\
\text { Coupled education-insurance } \\
\text { programs under discussion }\end{array}$ \\
\hline
\end{tabular}


Table 6B. Drought control measures.

\begin{tabular}{|c|c|c|}
\hline River basin & Supply-side measures & Demand-side measures \\
\hline Amudarya & $\begin{array}{l}\text { Water storage in single-year reservoirs } \\
\text { and lakes in delta region } \\
\text { Water allocation planning }\end{array}$ & $\begin{array}{l}\text { Attempts to implement technical, } \\
\text { economic, and legal water saving } \\
\text { measures } \\
\text { Increase in water use efficiency } \\
\text { Awareness raising }\end{array}$ \\
\hline Elbe & Water storage reservoirs & $\begin{array}{l}\text { Water-saving technologies } \\
\text { Water price mechanisms } \\
\text { Optimization of water resources use }\end{array}$ \\
\hline Guadiana & Surface and groundwater reservoirs & $\begin{array}{l}\text { Water pricing } \\
\text { Legal measures } \\
\text { Water-efficient crops }\end{array}$ \\
\hline Orange & $\begin{array}{l}\text { Dam infrastructure, including several } \\
\text { large interbasin transfer schemes }\end{array}$ & $\begin{array}{l}\text { Plans for demand management in South } \\
\text { Africa }\end{array}$ \\
\hline Rhine & $\begin{array}{l}\text { Large artificial basins } \\
\text { Redistribution between Rhine branches } \\
\text { using weirs in the Netherlands }\end{array}$ & $\begin{array}{l}\text { Raising awareness } \\
\text { Price mechanisms }\end{array}$ \\
\hline Tisza & $\begin{array}{l}\text { Six emergency reservoirs under } \\
\text { construction }\end{array}$ & No specific measures exist \\
\hline
\end{tabular}

All the basins need improved monitoring and more reliable scenarios for climate change and impact assessment, as well as prediction of flood and drought risks in a transboundary context. The investigation and comparison of different mechanisms for adapting to drought and floods and their implementation and monitoring are necessary. For example, in the Amudarya basin, research is needed to analyze the potential changes in flow patterns, to assess impacts on water supply and agriculture, and to develop measures to cope with these patterns. Modern approaches such as remote sensing can be used to monitor the extent of glacier reduction in Central Asia.

\section{Commonalities and Differences}

The following commonalities in coping strategies were identified in the river basins studied:

1. Structural measures for flood protection are implemented for all river basins.
2. The importance of nonstructural measures for flood protection is recognized in all the basins.

3. In the Rhine and Elbe basins, similar strategies for flood protection involving all kinds of measures are being used.

4. In the Guadiana and Amudarya, supply-based measures are practically exhausted.

The following differences in coping strategies between the basins can be observed:

1. All the basins will be affected differently by climate change.

2. The use of nonstructural measures differs greatly among the seven basins, ranging from active implementation to virtual nonexistence and the postponement of such measures for the future. 
Table 7. Need for improved monitoring and prediction and improvement of measures for coping with floods and droughts in six of the seven basins studied. The Nile, which runs through 10 countries, was not included because of insufficient data.

Table 7A. Improved monitoring and prediction and improvement of measures for coping with floods needed.

\begin{tabular}{|c|c|c|c|c|}
\hline River basin & $\begin{array}{l}\text { Improved monitoring } \\
\text { and prediction of } \\
\text { flood and drought } \\
\text { risk }\end{array}$ & $\begin{array}{l}\text { Structural measures } \\
\text { for flood control }\end{array}$ & $\begin{array}{l}\text { Nonstructural measures } \\
\text { for flood control }\end{array}$ & Social measures for flood control \\
\hline Amudarya & $\begin{array}{l}\text { Improved monitoring } \\
\text { Better prediction of } \\
\text { extreme events }\end{array}$ & $\begin{array}{l}\text { Updating and } \\
\text { maintenance }\end{array}$ & $\begin{array}{l}\text { Increase of water } \\
\text { storage in wetlands } \\
\text { in lower reach for } \\
\text { flood and drought } \\
\text { mitigation }\end{array}$ & $\begin{array}{l}\text { Improved warning systems } \\
\text { Better public awareness and } \\
\text { preparedness } \\
\text { Functional insurance }\end{array}$ \\
\hline Elbe & $\begin{array}{l}\text { Better prediction of } \\
\text { extreme events } \\
\text { under climate } \\
\text { change with } \\
\text { uncertainty ranges }\end{array}$ & $\begin{array}{l}\text { Maintenance and } \\
\text { updating }\end{array}$ & $\begin{array}{l}\text { Increasing natural } \\
\text { water retention and } \\
\text { retardation in } \\
\text { catchments }\end{array}$ & $\begin{array}{l}\text { Improved awareness } \\
\text { Improved preparedness }\end{array}$ \\
\hline Guadiana & $\begin{array}{l}\text { Quantitative and } \\
\text { qualitative monitoring } \\
\text { of aquifer bodies }\end{array}$ & $\begin{array}{l}\text { Needed only for } \\
\text { small creeks where } \\
\text { flash floods may } \\
\text { take place }\end{array}$ & $\begin{array}{l}\text { Needed in regard to } \\
\text { land-use patterns in } \\
\text { some areas of the } \\
\text { middle and lower } \\
\text { basin }\end{array}$ & $\begin{array}{l}\text { Needed only in areas of small } \\
\text { creeks where flash floods may take } \\
\text { place }\end{array}$ \\
\hline Orange & $\begin{array}{l}\text { Improved monitoring } \\
\text { and prediction of } \\
\text { extreme events, } \\
\text { particularly drought } \\
\text { prediction because } \\
\text { of marginal } \\
\text { agriculture }\end{array}$ & $\begin{array}{l}\text { Potential for dam in } \\
\text { lower Orange River }\end{array}$ & $\begin{array}{l}\text { Improved land-use } \\
\text { schemes } \\
\text { A general need for } \\
\text { improvement of } \\
\text { land management, } \\
\text { including wetland } \\
\text { rehabilitation }\end{array}$ & $\begin{array}{l}\text { Improved warning systems } \\
\text { Better awareness and preparedness } \\
\text { Improved insurance schemes }\end{array}$ \\
\hline Rhine & $\begin{array}{l}\text { Better low flow and } \\
\text { drought prediction }\end{array}$ & $\begin{array}{l}\text { Maintenance and } \\
\text { updating, which are } \\
\text { sometimes complicated } \\
\text { by conflicting } \\
\text { interests }\end{array}$ & $\begin{array}{l}\text { Creation of more } \\
\text { room for water } \\
\text { Spatial planning }\end{array}$ & $\begin{array}{l}\text { Raising awareness } \\
\text { Updating of flood emergency plan }\end{array}$ \\
\hline Tisza & $\begin{array}{l}\text { Improved monitoring } \\
\text { and prediction of } \\
\text { extreme events }\end{array}$ & $\begin{array}{l}\text { New reservoirs and } \\
\text { polders as set forth } \\
\text { in the Vásárhelyi } \\
\text { Plan }\end{array}$ & $\begin{array}{l}\text { Spatial river basin } \\
\text { planning } \\
\text { Increased water } \\
\text { storage } \\
\text { Distribution manag- } \\
\text { ement }\end{array}$ & $\begin{array}{l}\text { Integration of local population and } \\
\text { farmers } \\
\text { Improved information systems } \\
\text { Hazard awareness and } \\
\text { preparedness } \\
\text { Insurance packages }\end{array}$ \\
\hline
\end{tabular}


Table 7B. Improvement of measures for coping with droughts needed.

\begin{tabular}{|c|c|c|}
\hline River basin & Supply-side measures & Demand-side measures \\
\hline Amudarya & $\begin{array}{l}\text { Increase in water storage } \\
\text { Improved water supply management } \\
\text { Improvement of interstate cooperation }\end{array}$ & $\begin{array}{l}\text { Economic, legal, and technical water-saving } \\
\text { measures } \\
\text { Increase in water-use efficiency } \\
\text { Changes in cropping patterns }\end{array}$ \\
\hline Elbe & $\begin{array}{l}\text { Improved management in view of higher frequency } \\
\text { of droughts }\end{array}$ & $\begin{array}{l}\text { Optimization of water allocation schemes in case of } \\
\text { droughts } \\
\text { Changes in crop rotations } \\
\text { Introduction of new crop varieties }\end{array}$ \\
\hline Guadiana & Maintenance of two large reservoirs & $\begin{array}{l}\text { Control of illegal groundwater extraction } \\
\text { Introduction of water-efficient crops } \\
\text { Improved and more efficient irrigation methods } \\
\text { Water pricing } \\
\text { Exchange of groundwater rights }\end{array}$ \\
\hline Orange & $\begin{array}{l}\text { Increasing storage potential for surface water to } \\
\text { compensate for variability in rainfall }\end{array}$ & $\begin{array}{l}\text { Improved irrigation practices } \\
\text { Improved control of groundwater extraction }\end{array}$ \\
\hline Rhine & Enhanced drinking water supply by surface water & $\begin{array}{l}\text { Setting priorities for water use in low-flow and } \\
\text { drought periods } \\
\text { Incorporating the expected effects of climate change } \\
\text { in water management } \\
\text { More efficient use of water for irrigation }\end{array}$ \\
\hline Tisza & $\begin{array}{l}\text { Improved storage of spring flood water and its } \\
\text { distribution during growing season } \\
\text { Reactivation of fok-channel system and river } \\
\text { bolsons under discussion }\end{array}$ & $\begin{array}{l}\text { Setting priorities for water use during droughts } \\
\text { More efficient use of water for irrigation }\end{array}$ \\
\hline
\end{tabular}

3. Supply and demand measures are often basin specific and depend on climate and on environmental and socioeconomic conditions.

There are also a number of unique examples related to solving water management problems in our casestudy basins:

1. Managers in the Guadiana basin have attempted drought proofing through the intensive use of groundwater, although this may be not sustainable in the future.

2. Current socioeconomic problems seem to be more important to decision makers in the Amudarya basin than is the expected impact of climate change.

3. A variety of conditions and serious problems exist in the Nile, which is the largest basin.

4. Public awareness and actions have helped to improve water management, e.g., in the Tisza.

5. The guiding principles that have been developed for flood protection in the Rhine could be useful in other basins.

\section{Success Stories and Lessons Learned in Coping with Climatic Hazards}

Alhough people worldwide still continue to suffer the consequences of severe floods and droughts, there are some success stories in coping with extreme events on different continents, including the basins used in this study. These success stories range from improved flood preparedness to advanced anti-drought measures, and are listed in Table 8 . 
Table 8. Success stories in coping with extreme events.

\begin{tabular}{|c|c|c|}
\hline Location & Success story & Reference \\
\hline $\begin{array}{l}\text { The Rhine and Mosel, } \\
\text { Germany }\end{array}$ & $\begin{array}{l}\text { People living along the rivers are learning to deal with recurring } \\
\text { floods by extending precautionary measures and improving } \\
\text { distribution of information on flood protection. }\end{array}$ & $\begin{array}{l}\text { ICPR (1998) } \\
\text { Kundzewicz et al. (2002) }\end{array}$ \\
\hline The Rhine, Germany & $\begin{array}{l}\text { Integrated river management programs that include, e.g., the } \\
\text { restoration of flooplains through polder systems, are currently } \\
\text { compensating for some of the adverse effects of straightening the } \\
\text { Rhine and building dikes. }\end{array}$ & Demuth (1999) \\
\hline $\begin{array}{l}\text { The Mississippi and } \\
\text { Missouri basins, USA }\end{array}$ & $\begin{array}{l}\text { The great Mississippi-Missouri flood of } 1993 \text { had a significant impact } \\
\text { on U.S. flood management policy, which distributed management and } \\
\text { responsibilities among federal, state, and local authorities. }\end{array}$ & Josephson (1994) \\
\hline Japan & $\begin{array}{l}\text { A comprehensive flood control program was initiated in the late 1970s } \\
\text { based on an integrated approach that promotes water storage and } \\
\text { retardation in watersheds and structural measures for large rivers, } \\
\text { including very expensive infrastructure such as superlevees. }\end{array}$ & $\begin{array}{l}\text { Kundzewicz and } \\
\text { Takeuchi (1999) }\end{array}$ \\
\hline Thailand & $\begin{array}{l}\text { The country's drought preparedness was improved through a system } \\
\text { of prices and incentives and by strengthening the role of local water- } \\
\text { user organizations. }\end{array}$ & $\begin{array}{l}\text { Binnie et al. (1997) } \\
\text { Kundzewicz et al. (2002) }\end{array}$ \\
\hline $\begin{array}{l}\text { The Yakima River, } \\
\text { USA }\end{array}$ & $\begin{array}{l}\text { A spectrum of antidrought measures was introduced, including } \\
\text { additional wells, trading water rights, subsidies for set-aside land, tax } \\
\text { breaks for cattle sales, water conservation measures, etc. }\end{array}$ & $\begin{array}{l}\text { Glantz (1977) } \\
\text { Kundzewicz et al. (2002) }\end{array}$ \\
\hline
\end{tabular}

There have also been lessons learned in dealing with climatic hazards in all our case-study basins. In arid and semiarid regions, in which a warmer and drier climate is expected, the irrigation sector is likely to suffer particularly. Although solutions should be sought on a case-by-case basis, existing droughtproofing examples may provide a valuable reference for other regions in the future. In this regard, the Upper Guadiana experience shows that, wherever reliable groundwater supplies exist, these may act as a buffer to mitigate the potential effects of climate hazards over long periods. In the face of more severe stresses, learning from past mistakes may also prove instrumental in long-term ecosystem protection and in reducing water-table depletion.

The lessons learned in the Rhine and Elbe basins (ICPR 1998, WL/Delft Hydraulics 2003, DKKV 2004) can be summarized as follows. To reduce flood risk while simultaneously mitigating the effects of droughts and reversing the degradation of natural systems because of overdrainage, in addition to using traditional structural measures it is also necessary to:
- give rivers enough room to expand to delay runoff and reduce danger;

- manage water, trying first to retain, then to store, and only then discharge; and

- be aware of the danger, because a certain risk will always remain.

Also, it is clear that integrated management in the basin and transboundary cooperation are prerequisites for success.

The Thukela Dialogue was one of 17 dialogues commissioned by the International Dialogue on Water and Climate (Dialogue on Water and Climate 2002). Schulze (2005) highlights several lessons learned from this dialogue. One such lesson was that water management is not an end in itself but rather a tool for equitable and sustainable social and economic development. At present, water resources are often managed without a comprehensive understanding of the implications of climate 
Table 9. Lessons learned in dealing with climatic extremes.

\begin{tabular}{|c|c|}
\hline Category & Lessons learned \\
\hline $\begin{array}{l}\text { General lessons learned in } \\
\text { dealing with climatic extremes }\end{array}$ & $\begin{array}{l}\text { Recent climate variability and change seem to have increased flood and drought hazards } \\
\text { in many regions. } \\
\text { The higher adaptive capacity of the society, the more resources it can provide to cope } \\
\text { with extreme events, and the less tragic are the consequences of climate hazards. } \\
\text { Risk assessment of climatic hazards is necessary. } \\
\text { Public education and distribution of information on climatic hazards, e.g., risk maps, etc., } \\
\text { are important. }\end{array}$ \\
\hline
\end{tabular}

Lessons learned in dealing with Floods occur all over the world, even in arid regions.

floods

A large flood may recur again soon. As shown by several recent examples, there is a common misconception among the general public about, e.g., a so-called 100-year flood. Enhancing water storage, especially underground, mitigates both types of extremes: floods and droughts.

Structural measures such as building dikes and straightening rivers also have negative effects, including the shifting of flood problems downstream, adverse ecological impacts, and high maintenance costs.

There is often a false sense of security and an over-reliance on flood control works such as levees, reservoirs, etc., which in reality provide protection only below a certain threshold.

Human experience of a flood tends to reduce the amount of damage caused by the following flood, especially if it occurs within a short period of time.

Lessons learned in dealing with It is often becoming difficult to increase the amount of water in storage because of its droughts decreasing availability in general, and the adverse environmental and social impacts of reservoirs.

Intensive groundwater withdrawal may ensure social and economic development over a long period of time and thus provide an alternative solution for drought management, although some undesirable impacts may result from intensive pumping, e.g., water-table depletion, groundwater quality degradation, negative effects on streams and wetlands, or land subsidence.

Enhancing water storage, especially underground, mitigates both types of extremes: droughts and floods.

Adequate water management laws could improve drought preparedness in many regions.

change, and there is a real need for a holistic and integrated view of water-resource management. The effects of climate change and the need to adapt to them have to be built into a full water management cycle. Although present legislation does contain sound principles for coping, the lack of quantifiable information hampers decision making by water managers.

To summarize the latest studies that examine extreme climatic events (ICPR 1998, Kundzewicz et al. 2002, DKKV 2004) and experiences in the seven basins in this study, the lessons learned related to floods, droughts, and climatic extremes in general are presented in Table 9.

\section{CONCLUSIONS}

The future challenge is to develop strategies and measures to guarantee an adequate water supply to multiple users and to provide adequate protection against floods and droughts in river basins under changing climate conditions. The comparison of strategies in seven basins and the success stories and lessons learned in dealing with the climatic hazards summarized above help to validate strategies for coping with climate change in these and other large river basins worldwide.

Adapting water management to climate change requires changes in management practices and land use, technological development, diversification, 
modifications to the economic structures of households and regions, and awareness raising. The basic background information in planning for adaptation measures is the understanding of the exposure of the specific region to climate change and the sensitivity of the system to climate variability. For flood protection, structural and nonstructural measures along with social measures are important. Management of water supply and demand can be improved by optimizing demand management, using water-saving technologies, and encouraging more efficient use of available water by incorporating economic incentives, e.g., water pricing policies and water trading schemes. In addition, information measures in combination with risk mapping and improved warning systems are crucial to reducing vulnerability to climate change impacts. The potential strategies should be related to the growing conceptual understanding of the dynamics within interlinked social and ecological systems, and the integrated strategies in the basins should be related to behavioral drivers within societies. Economic instruments could be applied to recover the costs of adapting to the impacts of climate change.

However, the actual response strategies need to take into account the adaptive capacity of the natural and social systems under consideration, including social and political drivers. Therefore, building and strengthening adaptive capacity at the basin scale should be a central goal when it comes to dealing with climate change. Region-specific adaptation strategies should be developed by local water managers in discussion with the local population. This participative approach would allow sitespecific expert knowledge to be incorporated into the planning process and ensure that the response strategies consider local social and political drivers.

Water management related to extreme events is characterized by high complexity and involves uncertainty. Therefore, water-resource management should be approached from a broad perspective, taking into consideration the interests of different related sectors, different spatial and temporal scales, and transboundary issues. This requires the application of integrated water-resource management, which is defined as a process that promotes the coordinated management of water, land, and related resources to maximize economic and social welfare in an equitable manner without compromising the sustainability of vital ecosystems (Global Water Partnership Technical Advisory Committee (GWPTEC) 2000).
Moreover, projections of climate change and its impact on the water sector suggest that the goal of water managers should be to increase adaptive capacity to better cope with uncertain future developments rather than relying only on finding optimal solutions. Adaptive management is defined as a systematic process for improving management policies and practices by learning from the outcomes of implemented management strategies (Pahl-Wostl and Sendzimir 2005, Pahl-Wostl 2007). Therefore, strategies for coping with climatic hazards inevitably stress the need for integrated water-resource management in river basins, supplemented by adaptive management under uncertainty (Pahl-Wostl et al. 2007). Such an approach is especially needed in view of expected changes in climate in the 21 st century.

Responses to this article can be read online at: http://www.ecologyandsociety.org/voll3/iss2/art32/responses/

\section{Acknowledgments:}

The authors acknowledge the help of all the data suppliers, especially Chris Dickens (Orange) and Markus Wrobel (climate scenarios data), and are grateful to two anonymous reviewers who helped to improve the presentation of our material. The present contribution is a background publication within the NEWATER Project funded within the Sixth Framework Programme of the European Union (contract no. 511179).

\section{LITERATURE CITED}

Agaltseva, N. 2005. Climate changes impact to water resources within Amudarya River basin. Report for the NeWATER Amudarya Case Study, NIGMI, Tashkent, Uzbekistan.

Becker, A., and U. Grunewald. 2003. Disaster management: flood risk in central Europe. Science 300(5622):1099.

Benioff R., S. Guill, and J. Lee. 1996. Vulnerability and adaptation assessments; an international handbook. Version 1.1. Kluwer Academic, Dordrecht, The Netherlands.

Berz, G. 2001. Climatic change: effects on and 
possible responses by the insurance industry. Pages 392-399 in J. L. Lozán, H. Graßl, and P. Hupfer, editors. Climate of the 21st century: changes and risks. Office of Wissenschaftliche Auswertungen, Hamburg, Germany.

Beven, K. 2000. Rainfall-runoff modelling: the primer. Wiley, New York, New York, USA.

Binnie and Parners Ltd. 1997. Chao Phraya basin water management strategy for the Royal Thai government. Binnie and Parners, Bangkok, Thailand.

Burnod-Requia, K. 2004. Rapid environmental assessment of the Tisza River basin. UNEP, Vienna, Austria.

Demuth, N. 1999. Integrated flood management: the River Nahe catchment. Pages 227-234 in P. Balabanis, A. Bronstert, R. Casale, and P. Samuels, editors. River basin modeling, management and flood mitigation; proceedings of the final workshop. Office for Official Publications of the European Community, Luxembourg.

Demuth, S. 2005. Low flow and droughts: a European perspective. International Association of Hydrological Sciences (IAHS) Newsletter 82:7-8. [online] URL: http://grdc.bafg.de/servlet/is/8797/Low\% 20flows\%20and\%20droughts.pdf.

Department of Environmental Affairs and Tourism (DEAT). 1999. National state of environment report. DEAT, Pretoria, South Africa. [online] URL: http://www.ngo.grida.no/soesa/nsoer/ issues/climate/state.htm.

Dialogue on Water and Climate. 2002. Dialogue on water and climate in the Thukela basin of South Africa. Dialogue on Water and Climate, Wageningen, The Netherlands. [online] URL: http: //www.waterandclimate.org/dialogue/documents/ Thukela\%20website.pdf/.

Dukhovny, V., editor. 2002. Dialogue on water and climate: Aral Sea basin case study; final report. Scientific Information Center of the Interstate Coordination Water Commission, Tashkent, Uzbekistan.

Du Plessis, L. 2002. A review of effective flood forecasting, warning and response system for application in South Africa. Water SA 28(2):129137.

Eisenreich, S. J. 2005. Climate change and the European water dimension. European CommissionJoint Research Centre, Ispra, Italy.

European Environment Agency (EEA). 2004. Impacts of Europe's changing climate: an indicatorbased assessment. EEA Report Number 2. EEA, Copenhagen, Denmark.

German Committee for Disaster Reduction (DKKV). 2004. Flood risk reduction in Germany: lessons learned from the 2002 disaster in the Elbe region. DKKV, Bonn, Germany.

Glantz, M. H. 1977. The value of a long-range weather forecast for the West African Sahel. Bulletin of the American Meteriological Society 58:150-158.

Global Water Partnership Technical Advisory Committee (GWP-TEC). 2000. Integrated water resources management. TAC Background Paper Number 4. GWP, Stockholm, Sweden.

Hattermann, F. F., Z. W. Kundzewicz, V. Krysanova, and F. Wechsung. 2006. Integrated modeling of global change impacts in the German Elbe River basin: the GLOWA-Elbe Project. Pages 88-100 in Z. W. Kundzewicz and F. F. Hattermann, editors. Natural systems and global change. Research Centre for Agricultural and Forest Environment, Polish Academy of Sciences, Bukowska, Poland.

Horvath I., S. Kisgyorgy J. Sendzimir, and A. Vari. 2001. Flood risk management policy in the Upper Tisza basin: a system analytical approach. International Institute for Applied Systems Analysis, Laxenburg, Austria.

Intergovernmental Panel on Climate Change (IPCC). 2007a. Climate change 2007: synthesis report. IPCC, Valencia, Spain. [online] URL: http: //www.ipcc.ch/pdf/assessment-report/ar4/syr/ar4 syr. pdf.

Intergovernmental Panel on Climate Change (IPCC). 2007b. The physical science basis of climate change; Working Group I report, fourth assessment report on climate change. Cambridge 
University Press, Cambridge, UK.

International Commission for the Protection of the Rhine (ICPR). 1998. Action plan on flood defence. ICPR, Koblenz, Germany.

Jolonkai, G., and B. Pataki. 2005. Summary of the Tisza River Project and its main results: real-life scale integrated catchment models for supporting water and environmental management decisions. [online] URL: http://www.tiszariver.com/index.php? $\underline{\mathrm{s}=\text { results. }}$.

Josephson, D. H. 1994. The great midwest flood of 1993. Department of Commerce, NOAA, National Weather Service, Silver Spring, Maryland, USA.

Klein Tank, A. 2004. Changing temperatures and precipitation extremes in the Europe's climate of the 20th century. Dissertation, University of Utrecht, Utrecht, The Netherlands.

Klimaveränderung und Wasserwirtschaft (KLIWA). 2006. Climate change and consequences for water management. [online] URL: http://www.kliwa.de/

Krysanova, V., Z. W. Kundzewicz, I. Pinkswar, A. Habeck, and F. Hattermann. 2006. Regional socio-economic and environmental changes in central and eastern Europe and their impacts on water resources. Water Resources Management 20:607-641.

Krysanova V., T. Vetter, and F. Hattermann. 2008. Detection of change in the drought frequency in the Elbe basin: comparison of three methods. Hydrological Sciences Journal 53(3):519-537.

Kundzewicz, Z. W., and Z. Kaczmarek. 2000. Coping with hydrological extremes Water International 25(1):66-75.

Kundzewicz, Z. W., and K. Takeuchi. 1999. Flood protection and management: Quo vadimus? Hydrological Sciences Journal 44(3):417-432.

Kundzewicz, Z. W., S. Budhakooncharoen, A. Bronstert, H. Hoff, D. Lettenmaier, L. Menzel, and R. Schulze. 2002. Coping with variability and change: floods and droughts. Natural Resources Forum 26:263-274.

Llamas, M. R., and P. Martinez-Santos. 2005.
Intensive groundwater use: silent revolution and potential source of social conflict. ASCE Journal of Water Resources Planning and Management (September/October):337-341.

Maisch, M., A. Wipf, B. Denneler, J. Battaglia, and C. Benz. 1999. Die Gletscher der Schweizer Alpen - Gletscherhochstand 1850, Aktuelle Vergletscherung, Gletscherschwund-Szenarien. Nationales Forschungsprogramm "Klimaänderungen und Naturkatastrophen.” NPF 31 Final Report, Subproject 4031-033412. Swiss Federal Institute of Technology, Zurich, Switzerland.

Mathur A., I. Burton, and M. van Aalst, editors. 2004. An adaptation mosaic: a sample of the emerging World Bank work in climate change adaptation. World Bank, Global Climate Change Team, Washington, D.C., USA.

Middelkoop H., M. B. A. van Asselt, S. A. van't Klooster, W. P. A. van Deursen, J. C. J. Kwadijk, and H. Buiteveld. 2004. Perspectives on flood management in the Rhine and Meuse Rivers. River Research and Applications 20:327-342.

Ministry for the Environment. 2005. Principales conclusiones de la evaluación preliminar de los efectos en España por efecto del cambio climático. Ministry for the Environment, Madrid, Spain.

Ministry of Natural Resources. 2000. National report on climate change. Lesotho Meteorological Services, Ministry of Natural Resources, Maseru, Lesotho.

Ministry of Nature Protection of Turkmenistan (MNPT). 1999. The initial national communication on UN framework convention on climate change. MNPT, Ashgabat, Turkmenistan.

Ministry of Works, Transport, and Communication, Botswana (MWTCB). 2001. Botswana initial national communication to the United Nations Framework Convention on climate change. MWTCB, Gabarone, Botswana. [online] URL: $\underline{\text { htt }}$ p://unfccc.int/resource/docs/natc/botnc1.pdf.

Moyen, D. 1998. Action plan on floods. International Commission for the Protection of the Rhine, Bern, Switzerland.

Mukheibir, P., and D. Sparks. 2003. Water resource management and climate change in South 
Africa: visions, driving factors and sustainable development indicators; report for Phase I of the Sustainable Development and Climate Change Project. University of Cape Town, Rondebosch, South Africa.

Pahl-Wostl, C. 2007. Transition towards adaptive management of water facing climate and global change. Water Resources Management 21(1):4962.

Pahl-Wostl, C., and J. Sendzimir. 2005. The relationship between IWRM and adaptive management. NeWATER Working Paper 3. [online] URL: http://www.usf.uni-osnabrueck.de/p rojects/newater/downloads/newater rs03.pdf.

Pahl-Wostl C., J. Sendzimir, P. Jeffrey, J. Aerts, G. Berkamp, and K. Cross. 2007. Managing change towards adaptive water management through social learning, Ecology and Society 12(2): 30. [online] URL: http://www.ecologyandsociety.org/ vol12/iss $2 /$ art $30 /$.

Ososkova, T., N. Gorelkin, and V. Chub. 2000. Water resources of Central Asia and adaptation measures for climate change. Environmental Monitoring and Assessment 61:161-166.

Parry, M. L., editor. 2000. Assessment of potential effects and adaptation for climate change in Europe: the Europe Acacia project. Jackson Environmental Institute, University of East Anglia, Norwich, UK.

Republic of Tajikistan. 2002. Vital maps and graphics on climate change. Tajikistan Meteorlogical Services, Dushanbe, Tajikistan.

Schulze, R. E. 2005. Adapting to climate change in the water resources sector in South Africa. Pages 423-449 in R. E. Schulze, editor. Climate change and water resources in southern Africa: studies on scenarios, impacts, vulnerabilities and adaptation. Water Research Commission, Pretoria, South Africa.

Schulze, R. E., T. G. Lumsden, M. J. C. Horan, M. Warburton, and M. Maharaj. 2005. An assessment of impacts of climate change on agrohydrological responses over southern Africa. Pages 141-189 in R. E. Schulze, editor. Climate change and water resources in southern Africa: studies on scenarios, impacts, vulnerabilities and adaptation. Water Research Commission, Pretoria, South Africa.
Tarr, J. 2002. Projected impacts and vulnerability assessment. Pages 33-44 in Government of Namibia. Namibia: initial national communication to the United Nations Framework on Climate Change. [online] URL: http://unfccc.int/resource/docs/ natc/namnc1.pdf.

Turpie, J., H. Winkler, R. Spalding Fecher, R. Midgley, and G. Midgley. 2002. Economic impacts of climate change in South Africa: a preliminary analysis of unmitigated damage costs. Energy and Development Research Centre, University of Cape Town, Cape Town, South Africa.

United Nations (UN). 1994. International Convention to Combat Desertification (ICCD). UN, New York, New York, USA.

van der Hurk, B., A. Klein Tank, G. Lenderink, A. van Ulden, G. J. van Oldenborgh, C. Katsman, H. van den Brink, F. Keller, J. Bessembinder, G. Burgers, G. Komen, W. Hazeleger, and S. Drijfhout. 2006. Climate change scenarios 2006 for the Netherlands. Report WR 2006-01. Het Koninklijk Nederlands Meteorologisch Instituut Scientific, De Bilt, The Netherlands. [online] URL: http://www.knmi.nl/klimaatscenarios/knmi06/achtergrond/ index.html.

Vásárhelyi Plan Intersectorial Committee. 2004. Rebirth of the River Tisza. Vásárhelyi Plan Intersectorial Committee, Ministry of Environment and Water of Hungary, Budapest, Hungary.

WL/Delft Hydraulics. 2003. Water, climate and risk management; summary of the report on the Dutch dialogue on water and climate. Delft Hydraulics, Delft, The Netherlands. 